\title{
Supranational Attachment of European Elites and Citizens
}

\author{
GYÖRGY LENGYEL
}

Social identity, national and supranational attachment

WHILE RECENT RESEARCH HAS RAISED THE QUESTION of how support for integration is influenced by identity and utilitarian factors (Hooghe \& Marks 2005; Gabel 1998), in this essay we step back and ask what the underlying structures of supranational identity are. European identity, a complex phenomenon, may be approached by examining, among other aspects, attachment to Europe. Checkel and Katzenstein (2009), who depict European identity formation with darker colours of uncertainty and anxiety rather than hopes and assurance, distinguish between two versions of European identity. In one it is a process, an outcome of deliberation, exchange and the unintended consequences of spontaneous social processes such as increasing cross-border communication. In the other case supranational identity formation is more purposeful; it is the result of elites' identity-building efforts. There is little doubt about the ability of elites and the media to influence identity-formation using consciously-applied symbols (Bruter 2005), and even the projection of reinvented myths and a strengthened sense of imagined communities (Anderson 1983).

When people describe what and who they are, they can start out by using personality traits - modesty, courage, honesty - or from social categories like gender, age, family status and occupation. The latter categories designate basic social coordinates comprising social identity. The literature on identity distinguishes between social categories and social groups. To the extent that belonging is associated with internal cognitive, evaluative and emotional elements it may be considered to be social group membership, but when an external designation applies, 'belonging' may fall into a social category (Tajfel 1982; Brubaker \& Cooper 2000). It is equally important to understand, however, that some characteristics cannot be influenced, while others can be modified and moulded. Some are accepted as endowments, while others are constraints on life chances (Dahrendorf 1980). Personality traits, on the one hand, and belonging to social categories and groups on the other, are the two major dimensions of identities; this essay focuses on the social.

International comparative surveys have found that the typical markers of social identity that are regarded as most important are family status and occupation, 
followed by gender and age, then the variables of national and regional attachment. Belonging to a class, party, ethnicity or religion are less important markers all over the world, even though they may have great mobilising force in conflicts. The primary difference is not that family status, occupation, gender and age are less abstract or group-like categories than class, religion, nation or ethnicity; the difference in mobilising force derives mainly from the fact that the latter are supported by institutions, ideologies and organisational interests, while the categories of family, occupational and demographic identity are not - or are to only a smaller degree. In one Hungarian survey, in addition to enquiring about the above categories the parameter of 'identification with Europe' was also included. It was found that European identification followed gender, age, occupation, locality and nation, while far fewer respondents mentioned class, party, religion or ethnicity as a way of identifying themselves (Lengyel \& Göncz 2006).

In this essay I focus on the supranational attachment prevalent in the elites and publics of Europe. The reason that European attachment is considered here to be an aspect of supranational identity, instead of a proxy of it (Antonsich 2008), is that attachment associates with mostly emotional elements and not cognitive or evaluative ones. Unless otherwise mentioned, the primary source of the following analysis is the 2007 wave of the international comparative research project Intune (Integrated and United), supported by the Sixth Framework Programme of the European Commission (FP6). In 16 European countries parallel surveys were conducted both in the political and economic elite and within the adult population, concentrating on questions of identity, scope of governance and representation. Participating countries were Austria, Belgium, Bulgaria, Denmark, Estonia, France, Germany, Great Britain, Greece, Hungary, Italy, Poland, Portugal, Serbia, Slovakia and Spain: all EU-members except for Serbia. ${ }^{1}$ According to the survey design the elite samples consisted of 80 MPs and 40 top business leaders (bankers, managers and leaders of employers' organisations) per country, while the general population surveys were based on 1,000-strong representative samples of the respective countries.

\section{Elites and citizens, East and West: are there differences?}

In a previous paper which focused on elites, I tried to find out whether Eastern and Western European elites differed in regard to identity, assessment of EU goals and support for integration, and whether there were noticeable differences among East European countries in these respects (Lengyel 2009). At first glance, the East European elites had less commitment to the supranational entity, were less supportive of the institutions of integration and identified competition as the main goal of the EU. There were huge intra-regional differences as well: the Hungarian elite for example had above-average identification with Europe, support for integration and preference for the strengthening of competitiveness. Yet deeper analyses made clear that in some regards East-West differences disappeared as they were simply mediating the effects of other explanatory factors. Differences in symbolic or ideological

\footnotetext{
${ }^{1}$ Since in the Czech Republic and in Lithuania only the elites, and in Slovenia only the population were surveyed, they are therefore omitted from the present analysis.
} 
aspects - identity and goals - disappeared, while they remained in the explanation of pragmatic aspects: the East European elites remained the more moderate supporters of integration and supranational institutions when this support was investigated together with cultural, social and other differences (Lengyel 2008). What actually explained the supranational commitment of the elite was the level of education and social resources. In this regard, however, there was found to be a more significant discrepancy between the elites of the founding EU members and later EU entrant countries than between Eastern and Western elites.

In this essay I return to the question of the symbolic and pragmatic attitudes towards the EU of different country groups, investigating public opinion in the respective countries as well as the views of political and economic elites.

In general the research found that the East-West divide has no significant effect on European attachment within political and economic elites while there is a weak impact of these territorial and historical differences on European attachment within the general population. Country differences, however, prove to be important in terms of European attachment, especially among elites. There are no significant differences between East and West European economic elites in terms of attachment to their countries but political elites differ from each other according to country groups more than the population does.

There are greater differences concerning pragmatic issues than symbolic ones. Statistics for attitudes to further unification in Table 1 are stronger (and in several cases more significant) than they are for attitudes concerning European attachment. The opinion of economic elites about further support for unification is correlated more strongly with geographical factors such as the East-West distinction than is the case for the political elites and the general population.

East-West comparison of the political and economic elites reveals no significant differences, though the 'very attached' categories diverge in both elite groups. The difference is that in Western elites the rate of those 'very attached to Europe' is higher than in their Eastern counterparts. Since, however, samples are smaller here, the divergence does not reach a level of significance whereas in the general population this rate is a little higher in the East - which is sufficient to cause significant deviation

TABLE 1

IMPACt of EAST-WeSt AND COUNTRy DifFERENCES ON ATTACHMENT to EuROPE, TO THE COUNTRY AND ON THE SUPPORT FOR UNIFICATION (CRAMER'S $V$ VALUES)

\begin{tabular}{|c|c|c|c|}
\hline & Attachment to Europe & Attachment to the country & Support for unification \\
\hline \multicolumn{4}{|l|}{ Political elite } \\
\hline East-West & ns & $0.14 * * * *$ & $0.183^{* * * *}$ \\
\hline Country & $0.237 * * * *$ & $0.289^{* * * *}$ & $0.31 * * * *$ \\
\hline \multicolumn{4}{|l|}{ Economic elite } \\
\hline East-West & ns & ns & $0.259 * * * *$ \\
\hline Country & $0.252 * * * *$ & $0.268^{* * * *}$ & $0.354 * * * *$ \\
\hline \multicolumn{4}{|c|}{ General population } \\
\hline East-West & $0.023^{*}$ & $0.09 * * * *$ & $0.074 * * * *$ \\
\hline Country & $0.168 * * * *$ & $0.171^{* * * *}$ & $0.238 * * * *$ \\
\hline
\end{tabular}

Notes: $* * * *$ level of significance is $0.0001 ; * * *$ level of significance is $0.001 ; * *$ level of significance is $0.01 ; *$ level of significance is $0.05 ; \mathrm{ns}=$ not significant. 
owing to the large sample. In other categories there is no remarkable deviation, although in the Western samples the 'somewhat attached' response is a little more prevalent.

Against this, there is significant divergence between elites and the population as regards European attachment: over one-third of members of the elites (two-fifths of Western elites) are strongly attached while the corresponding rate among the population is less than a quarter. This difference is more marked in West European countries (see Table 2).

As one could expect, both elites and the population are much more attached to their country than to Europe. Within the Eastern political elites and populations there is stronger attachment to one's own country than is found for West European countries (with no significant deviation being found in the economic elite in this respect; see Table 3). The divergence between the elite and the population as regards national attachment is less marked than for European attachment. National attachment was higher in the political elite than in the population and the economic elite. Due to the fact that, according to the sample design, the political elites were members of the national parliaments, a strong national attachment was more markedly asserted as a norm in this case. It is worth noting that, while in the case of supranational attachment the two elite groups were close to each other, in the case of national attachment the economic elite is closer to the population, especially in the East.

As regards pragmatic implications of attitudes to the EU, this was approached by considering the degree to which further integration was supported. This was found to

TABLE 2

European AtTachment of Elites and the Population in WeSt And EAST Europe (\% ANSWering THAT UNIFICATION SHOULD BE STRENGTHENED; \% OF ANSWERS RANKED 7 AND ABOVE ON A 10-POINT SCALE)

\begin{tabular}{|c|c|c|c|c|}
\hline & Political elite & Economic elite & General population & \\
\hline & $(n=1,234)$ & $(n=636)$ & $(n=15,760)$ & Cramer's V \\
\hline West & 39.6 & 39.5 & 22.2 & $0.115^{* * * *}$ \\
\hline East & 36.8 & 34.4 & 24.1 & $0.096^{* * * *}$ \\
\hline Cramer's $V$ & ns & ns & $0.023^{*}$ & \\
\hline
\end{tabular}

Note: $* * * * l e v e l$ of significance is 0.0001 .

TABLE 3

Attachment of Elites and the Population to Their Country in West and East Europe (\% ANSWERING THAT UNIFICATION SHOULD BE STRENGTHENED; \% OF ANSWERS RANKED 7 AND ABOVE ON A 10-POINT SCALE

\begin{tabular}{|c|c|c|c|c|}
\hline & Political elite & Economic elite & General population & \\
\hline & $(n=1,244)$ & $(n=641)$ & $(n=16,069)$ & Cramer's V \\
\hline West & 70.7 & 62.1 & 57.0 & $0.055^{* * * *}$ \\
\hline East & 81.6 & 63.7 & 65.2 & $0.065^{* * * *}$ \\
\hline Cramer's $V$ & $0.14 * * * *$ & ns & $0.093 * * * *$ & \\
\hline
\end{tabular}

Note: $* * * * l e v e l$ of significance is 0.0001 . 
be significantly higher in Western elites than in the Eastern European elites. Especially great were the deviations in the economic elites, while similar but less marked differences were found in the samples of the populations. To be more accurate, the question on unification was answered in the positive by both the elite and the majority of the population. ${ }^{2}$ Table 4 below indicates strong support as shown in the percentage of responses ranked $7-10$ on a 10-point scale. It can also be gleaned that the deviation between the opinions of the elite and the population in regard to supporting further integration is greater in the West European countries than in Eastern Europe. It is true, however, that in the West a significantly higher proportion of the population supports further unification when compared to Eastern Europe.

West and East European citizens do differ in many other ways concerning their perceptions of the EU: West Europeans think (in significantly higher proportions) that they would be seriously neglecting their duties if they did not vote in elections for the European Parliament; they trust more in fellow Europeans; and they consider that what happens to Europe impacts on their personal life. West Europeans are significantly more satisfied with the way democracy works in their countries $(51 \%$ compared to $39 \%$ ). They were, however, more concerned and divided about the economic conditions of their country in 2007. A higher proportion of them felt that economic conditions had either got better or worse, while a higher proportion of East Europeans felt no change in this respect.

As for evaluation of their country's EU membership, one can see a similarity and yet a basic difference. West Europeans report (in significantly higher proportions) that EU membership of their country is a good thing. However they mention (significantly over the average) that membership is a bad thing as well. This was possible because there was a third option which could have been voiced spontaneously, that it was neither good nor bad, and East Europeans were over-represented in their choice of that option.

In terms of threats caused by the fact that people, money and ideas travel quickly across borders, there is no major difference between East and West Europeans: more

TABLE 4

SUPPORT FOr UNIFICATION WITHIN WEST AND EAST EUROPEAN EliteS AND THE GENERAL POPULATION (\% ANSWERING THAT UNIFICATION SHOULD BE STRENGTHENED; \% OF ANSWERS RANKED 7 AND ABOVE ON A 10-POINT SCALE)

\begin{tabular}{|c|c|c|c|c|}
\hline & Political elite & Economic elite & General population & \\
\hline & $(n=1,174)$ & $(n=628)$ & $(n=14,522)$ & Cramer's $V$ \\
\hline West & 66.8 & 70.6 & 40.9 & $0.124 * * * *$ \\
\hline East & 48.4 & 45 & 33.3 & $0.097 * * * *$ \\
\hline Cramer's V & $0.183^{* * * *}$ & $0.259 * * * *$ & $0.074 * * * *$ & \\
\hline
\end{tabular}

Note: $* * * *$ level of significance is 0.0001 .

\footnotetext{
${ }^{2}$ The question was: 'Some say European integration should be strengthened. Others say it already has gone too far. What is your opinion? Please indicate your views using a 10-point scale, "1" means unification "has already gone too far" and "10" means "it should be strengthened". What number from this scale best describes your position?'
} 
than half in both groups think that these are threats to security and well-being. As for culture and way of life, the average proportions are also similar, but East Europeans feel that these globalisation phenomena are more serious threats.

Further shades of opinion can be discerned from the picture of an East-West dichotomy if we subdivide the group of Western countries and examine the Mediterranean countries (Italy, Spain, Portugal and Greece) as a separate group (Conti et al. 2010). In terms of European attachment, this causes little change, but in regard to attachment to one's country, there is very strong divergence between the Western and Mediterranean elites. Among political leaders, the Mediterraneans are characterised by similar levels of attachment to the Eastern Europeans. In the economic elites, national attachment is even higher than among the Eastern elites. The difference between elites and the population is also more pronounced in Mediterranean countries than for Western or Eastern groups. In all countries political elites show significantly higher attachment to their countries than their corresponding populations do. While in the West and in the East the national attachment of economic elites is close to that of the population, in the Mediterranean region it is closer to the attitude of the political elite.

Taking the Mediterranean countries separately, the truly salient difference was found in respect to pragmatic attitudes to the EU. The previously found higher level of support for the EU in the West was largely due to well above average support for the EU in the Mediterranean countries. This finding applies particularly to the political elites, but it is also valid for the economic elite and the population. As regards popular support for the EU, it appears to be the same in the East and in the West when the latter is taken into account without the Mediterranean countries. Outstandingly high EU-support can be found among the Mediterranean population.

\section{Hard and soft Euroscepticism}

Opinion polls of the Hungarian public have registered that, after initial heightened expectations, it soon became disillusioned by the EU. Indeed, even when viewed from an international perspective there was a considerable decline in the quantity of positive answers to questions like: 'Do we benefit from the EU?' or 'Is joining the community useful for the country?' It is, however, expedient to differentiate between the concepts of soft and hard Euroscepticism in opinion polls, just like in policy analyses. In political science hard scepticism characterises a position that is in opposition to the EU and integration in principle, while soft Eurosceptics do not object to the EU in theory but question specific policies (Szczerbiak \& Taggart 2008). Thus, in opinion polling, we have to distinguish between those who symbolically reject a supranational identity (on a theoretical, ideological or emotional basis) from those who find no benefit in such integration or do not regard it as positive.

Soft Euroscepticism alludes to pragmatic-utilitarian attitudes that could easily change with changes in policy. Hard Euroscepticism refers to symbolic, ideological or emotional rejection, which is presumably more difficult to change and has different motivational origins.

According to our study, somewhat more than one-third of the European population was found to hold a hard Eurosceptic position, while the corresponding rate among 
political and economic elites was only between $13 \%$ and $16 \%$. Looking at countries individually in Table 5, the British, Bulgarian, Greek and Estonian, as well as the French, Spanish, Slovakian and Serbian populations, had above-average aversion to the supranational entity. The elites, as seen earlier, were less unsympathetic than the populations, with the exception of the British political elite, which was as unattached to Europe as the British population.

A very small proportion of the elites thought that their countries did not profit from EU membership, as compared to over a quarter of the population. Particularly negative were the attitudes of the British and Hungarian populations, and somewhat less so the French and German adult populations. Among the political elites, the Danish, Hungarian, Polish and Serbian appeared to be sceptical. Among the economic elites, the low rate of mentions resulted in a floor effect and there was no significant correlation. A total of $18 \%$ of the general population rejected further unification, compared to $11 \%$ and $7 \%$ of the elites. The Austrian and British public were particularly sceptical, with the political elites of the latter sharing the opinion of the population. The case of the Estonian elites is particularly remarkable since they rejected further enlargement of the EU even more strongly than the general population.

From background calculations it turns out that neither East-West nor East-WestMediterranean country group differences are correlated to hard Euroscepticism. In other words East, West and Mediterranean elites do not differ concerning a lack of European attachment. Nonetheless, they do differ in terms of soft Euroscepticism. While, compared with other elites, the Eastern elites opposed further unification most, in the case of the general population it was the Western European population that was above-average in its negative opinion. Taking a closer look however, it turns out that there is a huge difference within the 'Western' block: the Mediterranean public was the least sceptical concerning unification, and the Western public in the narrow sense was the most sceptical. The same holds true in the case of the other indicator of soft Euroscepticism: one-third of the Western, but less than one-sixth of the Mediterranean public, felt that their country has not benefited from integration. Among the Eastern countries one can see below-average hard Euroscepticism in Hungary and Poland. On the other hand, soft Euroscepticism in the Hungarian population is found to be among the highest of all countries: more than half feel that the country has not benefited from being a member state of the EU.

\section{Attachment to Europe, attachment to the EU}

According to critics the presentation of questions about European attachment instead of EU attachment in international surveys may reflect the deliberate intention of supranational elites to manipulate identity formation (Immerfahl et al. 2010). After all, people who denigrate the EU as an institution may well be attached to Europe, while attachment to the EU without attachment to Europe is less likely to happen, and for this reason attachment to Europe could be considered a symbolic aspect of supranational identity. Even if there is no conscious attempt at manipulation, it should indeed be examined whether there is a significant difference between European attachment and EU attachment. 


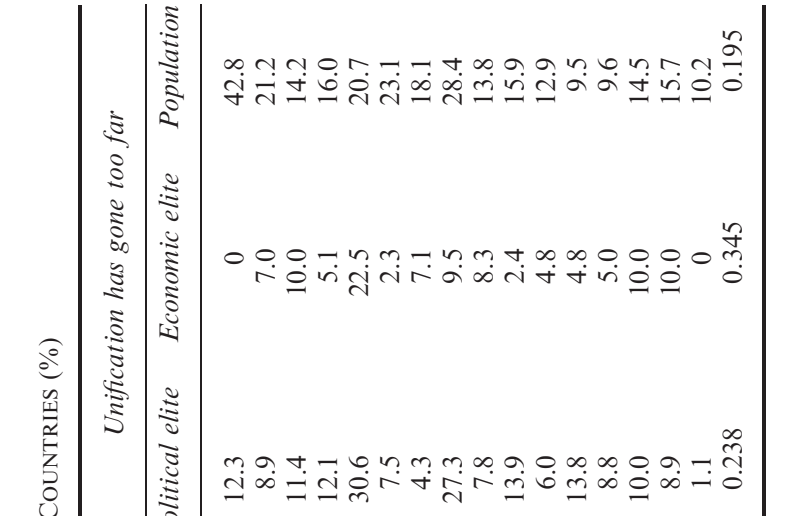

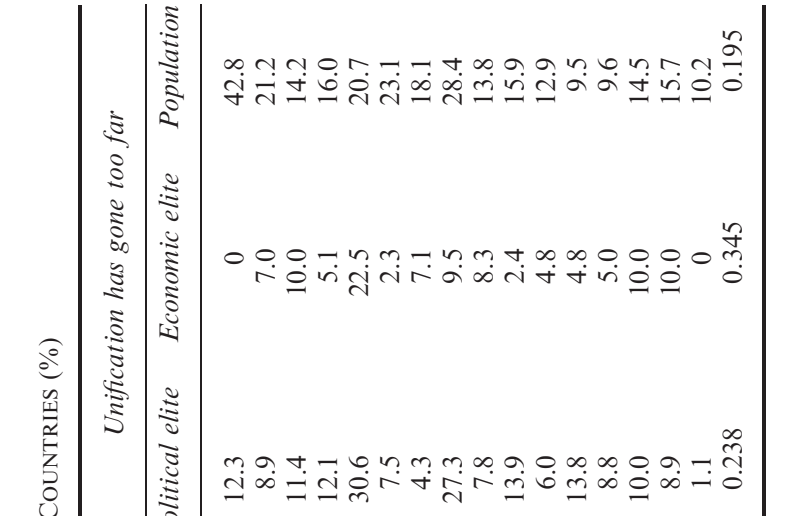

苛

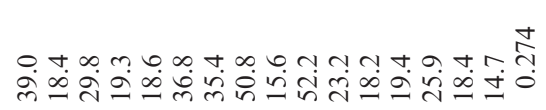

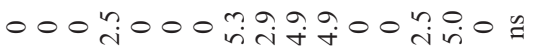

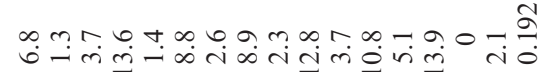

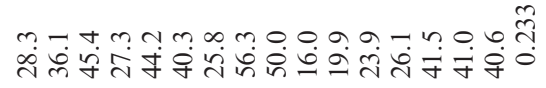


It stands to reason that the EU institutions themselves generate a European identity, but it would be a mistake to overlook the European identity that exists independently of the EU. This concerns not only public opinion in non-EU member countries but also the idea that there is a continental identity in the public of the member countries that is free from the frame of the EU. Eurobarometer approached the issue in different survey waves with different wording: in 1991 it used the phrases 'European Community' and 'Europe as a whole', while in 1995 it utilised 'European Union' and 'Europe as a whole'. The question is whether there is a significant difference between European and EU attachment. This can be answered in two ways: by comparing the results for different years, and by comparing the results of the same survey in respect of both differences between responses on attitudes to the EU and to Europe more generally. First I compare the results from 1991 and 1995 (see Table 6).

According to these measures there was no significant difference between attachment to Europe and to the EC or EU. There was a slight drop between 1991 and 1995 concerning both continental and institutional attachment, but no variance within the same year. The problem with comparing the results of different years however, is that there are many changing conditions which may influence results, including, among other variables, the mood of the target population and the political context. The problem with asking parallel questions in the same questionnaire on the other hand is that questions concerning Europe or the EU may have an equalising mutual influence on each other.

A more precise result could be expected from an empirical survey applying split ballots in a given year. If two statistically comparable sub-samples are addressed with questions - one concerning 'European' and the other 'EU' attachment — at one and the same time, in this way both changing political contexts and question cross-effects could be neutralised. In a recent Hungarian omnibus survey we investigated the question using this design (see Table 7).

TABLE 6

Attachment to Europe And to the European Community/European Union, 1991 AND 1995, General Population, Member States (\%)

\begin{tabular}{lccccc}
\hline & \multicolumn{2}{c}{$1991^{*}$} & & \multicolumn{2}{c}{$1995^{* *}$} \\
\cline { 2 - 3 } \cline { 5 - 6 } & $\begin{array}{c}\text { The European } \\
\text { Community }\end{array}$ & $\begin{array}{c}\text { Europe as } \\
\text { a whole }\end{array}$ & & $\begin{array}{c}\text { European } \\
\text { Union }\end{array}$ & $\begin{array}{c}\text { Europe as } \\
\text { a whole }\end{array}$ \\
\hline Very attached & 12.3 & 13.1 & & 9.3 & 9.5 \\
Fairly attached & 38.3 & 37.7 & & 35.2 & 34.3 \\
Not very attached & 32.2 & 30.2 & & 38.3 & 37.4 \\
Not attached at all & 17.2 & 18.9 & & 17.2 & 18.9 \\
$N$ & 12,286 & 13,155 & & 15,681 & 15,684 \\
\hline
\end{tabular}

Notes: *'People may feel different degrees of attachment to their town or village, to their region, to their country, to the European Community or to Europe as a whole. Please tell me how attached you feel to ... ?' **'People may feel different degrees of attachment to their town or village, to their region, to their country, to the European Union or to Europe as a whole. Please tell me how attached you feel to ... ?'

Source: Eurobarometer 1991/2 and 1995/2, available at: http://www.gesis.org/eurobarometer/data-access/, accessed 31 May 2010. 
TABLE 7

Attachment to Europe And to the European Union, 2010, General Population, Hungary

\begin{tabular}{lcccr}
\hline & \multicolumn{2}{c}{ Sample A } & & Sample B \\
\cline { 2 - 3 } & (Attachment to Europe) & & (Attachment to the EU) & Together \\
\hline Very attached & 37.4 & 23.0 & 30.2 \\
Fairly attached & 41.1 & 36.0 & 38.6 \\
Not very attached & 16.2 & 31.3 & 23.7 \\
Not attached at all & 4.9 & 9.3 & 7.1 \\
Don't know & 0.4 & 0.4 & 0.4 \\
$N$ & 506 & 505 & 1,011 \\
\hline
\end{tabular}

Note: Cramer's $V=0.22 * * * *$.

Source: author's calculation.

As one can see from these results, the context of Europe and the EU is not neutral. Although the majority of the Hungarian population is attached both to the EU and to Europe, the intensity of attachment is significantly stronger in the case of Europe. The problem with this result is that it is based only on Hungarian data and its wider relevance would need to be verified. Although it seems to be reasonable to suppose that there are similar differences in other countries as well, it may happen that postcrisis Hungary is a special case in this respect, at least as far as the size of attachment variance is concerned.

\section{Further differences within Eastern Europe}

There are massive differences in attitudes among the countries of Eastern Europe. The Estonian elites are sceptical (Vetik 2003) while the Polish and Hungarian elites are enthusiastic about symbolic supranational issues. ${ }^{3}$ Concerning support for integration, the picture is more shaded when controlled for the use of different variables, but the Estonian elites remain sceptical and the Hungarians remain supportive of supranational institutional solutions. (A relative rapprochement of the elite and the public is more typical of Mediterranean countries which appear to prefer social security to economic competitiveness.)

Turning the attention to the general public one can see that Hungary ranks well above average concerning the proportion of those who felt very attached to Europe. The high rate of symbolic supranational identification exceeds not only the East European but the West European and Mediterranean averages as well. This population-together with the Bulgarians - exceeds most of the rest in terms of national attachment. In pragmatic terms however, the Hungarian and Bulgarian populations are less enthusiastic. Only a quarter of the Hungarian, less than one-third of the Bulgarian (and less than a quarter of the Estonian) population supported further unification in contrast to half of the Polish population, and more than half of the Mediterranean population (see Table 8).

\footnotetext{
${ }^{3}$ Such differences, however, are present among the Western elites as well; let us here just mention the extremes: the scepticism of the British and the supportiveness of the French elites.
} 
While three-quarters of Mediterraneans and two-thirds of West Europeans think that their country's EU membership is a good thing, only three out of five of East Europeans think this way. Positive evaluation is especially low in the case of Hungary where almost a quarter think that EU membership is a bad thing (see Table 9). This is not exceptional, it is actually close to the West European average, while the spontaneously offered 'neither good, nor bad' type of answer is represented at well above the average rate. What is strange is that a negative evaluation from a pragmatic perspective is accompanied by a strong symbolic supranational attachment.

\section{Long-term perspective and fieldwork}

It is worth making some remarks concerning the long-term expectations of the EU. ${ }^{4}$ One is that the citizens of old EU member states are more pessimistic than those of the

TABLE 8

Attachment and Support of EASt European Countries' Populations (\%)

\begin{tabular}{|c|c|c|c|}
\hline & Very attached to Europe & Very attached to the country & Support of unification \\
\hline West & 22.4 & 55.6 & 32.4 \\
\hline Mediterranean & 21.5 & 59.1 & 54.1 \\
\hline Bulgaria & 16.3 & 77.9 & 30.5 \\
\hline Estonia & 14.2 & 68.7 & 22.2 \\
\hline Hungary & 46.5 & 76.4 & 25.5 \\
\hline Poland & 23.6 & 68.2 & 50.3 \\
\hline Serbia & 18.9 & 61.2 & 39.2 \\
\hline Slovakia & 18.9 & 40.7 & 30.4 \\
\hline Phi $=$ & $0.16^{* * * *}$ & $0.223 * * * *$ & $0.193 * * * *$ \\
\hline$N=$ & 16,119 & 14,522 & 16,069 \\
\hline
\end{tabular}

Note: ****level of significance is 0.0001 .

TABLE 9

Evaluation of the Country’s EU-Membership in EASTERn Europe (\%)

\begin{tabular}{lccc}
\hline \multicolumn{4}{c}{$\begin{array}{c}\text { Generally speaking, do you think that the country's membership of the European } \\
\text { Union is ...? }\end{array}$} \\
\cline { 2 - 4 } & A good thing & A bad thing & Neither good nor bad (spontaneous) \\
\hline West & 67.2 & 24.7 & 7.9 \\
Mediterranean & 78.0 & 9.9 & 12.1 \\
Bulgaria & 62.7 & 8.0 & 29.3 \\
Estonia & 66.6 & 8.6 & 24.8 \\
Hungary & 43.1 & 9.5 & 34.3 \\
Poland & 77.1 & 5.4 & 3.4 \\
Slovakia & 58.9 & 18.1 & 20.8 \\
Serbia & 61.1 & & \\
\hline
\end{tabular}

Notes: Cramer's $V=0.236^{* * * * ;} N=15,641$.

\footnotetext{
'Expectations of European citizens regarding the social reality in 20 years' time', Flash Eurobarometer \# 227, The Gallup Organization, 2008.
} 
new members, and the majority envisage a deterioration of their living conditions in the long run and a growing gap in social differences. So far we have found that the citizens of old member countries were more optimistic, satisfied and supportive than the citizens of new entrant states. Perhaps this was so because respondents were asked usually to consider the near future, but if they are asked about prospects over a longer time reference, their perspective is reversed. For citizens of Western countries 'there is nowhere to go but down' which may be a consequence of the recession or integration. In the latter case, overtly or covertly the pre-enlargement state could be conceived as a Pareto optimal in that some members can only be promoted to the detriment of some others and citizens of older member countries fear they could become these 'others'.

The opinions of the citizens of new member countries who are less optimistic and supportive in the present in terms of living standards, competitiveness or social security may reflect a catch-up effect, that 'there is a lot to make up for' in terms of living standards, competitiveness or social security. Institutional conditions might also support the attitude that looks upon the EU (however suspiciously or inimically) as a power that is able to regulate national administrations, despite - or because of - the crisis. Such opinions are, obviously, not free from contradictions, particularly when the formations in question are distant and rather abstract and can be easily coupled with views that associate threats with integration. This was suggested, for example, in a sociological fieldwork exercise carried out by students at Corvinus University of Budapest who had to keep a logbook in addition to questionnaires, interviews and visual documentation, in which they had to describe the interview situations, comments elicited by the questions and problems of interpretation. From a methodological point of view, these logbooks are very instructive as they reveal something that is regrettably overlooked due to a lack of time, even when the protocol of inquiry is observed strictly. They may provide examples of unexpected aspects of the issue under investigation. This is an example from a logbook of how a negative EU image is mitigated by a question on national economic policy:

The respondent was a lady in her forties, whose son also arrived a little after our entry and who also listened to the questionnaire attentively. The lady was vehemently against the EU, not veiling her political views. Interestingly, when the question concerning 'keeping strategic industries in national hands' was asked, it reminded her of corruption and this drove her away from hostility to the EU towards a more middle-of-the road attitude. This response was also often met with in comments from other informants. (Geszler et al. 2009)

Essentially, the point is that pragmatic opinions on the EU are often motivated by the principle of the 'lesser evil', the need for regulation and simply by utilitarianism.

The Intune survey data contained a battery of questions which also concerned the long-term character of the EU. The majority of the European population agreed with all the investigated potential long-term aims of the EU: social security unification; a unified tax system; a single foreign policy; and equalisation of regional differences. They were most supportive of equalisation and a single foreign policy, but four out of five supported the idea of a common social security system and two out of three a unified tax system as well.

However, there are significant differences according to regions concerning these long-term policy dimensions. Regarding the social security system and regional 
equalisation, East Europeans supported long-term unification more strongly than the rest (see Table 10). Concerning a single foreign policy the opinions of East Europeans and Mediterraneans were similar, and were close to each other concerning a unified tax system as well. However, here the opinions of Mediterraneans were more supportive.

\section{Knowledge and attachment-clarification or growing uncertainty?}

Through the above-mentioned Intune cooperative effort we carried out a deliberative poll on a representative sample from a small region. One subject of the inquiry was unemployment, and the other was participant views on the role and goals of the EU (Göncz 2009). The method combined a standard opinion poll, intensive small-group debates involving citizens who originally participated in the survey, and hearings of experts. Through the deliberations of the small groups there were some changes in attitudes to the EU: it was seen as being more important to support integration and to improve EU competitiveness and solidarity, but on the whole, there was a decrease in the number of those who felt that what was going on at the EU level had an effect on their lives. Before deliberation two-thirds of respondents had positive attitudes yet after the weekend discussions only half did. What happened? Did the participants become disillusioned or uncertain after the debates and expert presentations? An initial, relatively vague though basically positive image was modified-for there was a great degree of ignorance about the EU-and counterarguments and conflicting opinions might also have caused the participants' uncertainty. Experts often referred to numerical facts and mentioned that information (for example, about EU grants) was available on the internet, which to a certain extent frustrated the older participants who must have felt that they were excluded from something that was also their business, something that had begun to interest them.

It was not a negative attitude (distrust of the EU) that increased, since participants were ready to forward a fifth of their taxes to the EU after the deliberation compared to a tenth at the beginning, and evaluation of the competence of EU decision-makers also increased. What happened was that the new information brought opinions closer to reality. The same survey revealed that (concerning knowledge gain) there was a systematic difference between textual and numeric questions: quantitative information was harder to remember (Fishkin et al. 2009).

TABLE 10

The Character of the European Union in 10 Years (General population, \% of those Who are STRONGLY IN FAVOUR OF ...)

\begin{tabular}{lcccc}
\hline & $\begin{array}{c}\text { Common social } \\
\text { security system }\end{array}$ & $\begin{array}{c}\text { Unified tax } \\
\text { system }\end{array}$ & $\begin{array}{c}\text { Single foreign } \\
\text { policy }\end{array}$ & $\begin{array}{c}\text { More help for regions } \\
\text { with difficulties }\end{array}$ \\
\hline West & 24.1 & 22.6 & 24.5 & 22.8 \\
Mediterranean & 35.1 & 31.8 & 34.5 & 46.8 \\
East & 40.4 & 28.3 & 32 & 51.2 \\
Cramer's $V$ Phi & $0.18 * * * *$ & $0.13 * * * *$ & $0.13 * * * *$ & $0.22 * * * *$ \\
$N$ & 16,514 & 16,276 & 16,316 & 16,685 \\
\hline
\end{tabular}


This phenomenon can also be checked by Intune comparative data. We find that substantially fewer people can answer questions about quantitative topics than questions involving qualitative information. In 2007, at the time of the survey, the number of EU members had just been raised, therefore both 25 and 27 were accepted as correct answers. Even so, barely over one-third of European respondents representing the general population could say how many members the EU had. It was also found - and this can be seen in Table 11 - that possessing correct quantitative knowledge correlated positively with European attachment, and to a lesser extent, with support for further integration and with the perception of the personal consequences of EU membership.

By contrast, qualitative knowledge revealed the reverse effect. The overwhelming majority of individuals correctly identified anti-unemployment efforts and health care as being among national (in some member countries sub-national or combined) competences, and less than a quarter of respondents thought that these areas fell under the competence of the EU (or they could not answer). However, among those whose knowledge was incorrect, European attachment and support was significantly overrepresented. In this case it was not the effect of a lack of knowledge but, conversely, positive attachment that led to the illusion in which policy-related discourse and actual policy competences were fused. The wording 'mainly dealt with' in the policy-related questions also allowed for the illusory interpretation that where there is much discussion about plans for the future, there is also decision-making competence.

\section{Identity and attachment}

One may specify culture and citizenship as being the main factors that constitute national and European identity. Our empirical investigations, however, revealed support for other more primordial, unchangeable factors determined by birth. East European elites were over-represented among those who defined primordial factors as preconditions for national and European identity (Lengyel \& Göncz 2009). Another interesting finding in this regard is that the German and French elites did not ascribe significance to their native land or parents as preconditions of national identity (when

TABLE 11

Attachment, Support for Integration and Feeling of Personal Consequences from EU MEMBERSHIP By KNOWLEDGE ABOUT THE EU (GENERAL POPULATION, \%)

\begin{tabular}{llccc}
\hline Question* & Answer & $\begin{array}{c}\text { Attachment } \\
\text { to Europe } \\
\text { (very attached) }\end{array}$ & $\begin{array}{c}\text { Support for } \\
\text { integration } \\
\text { (strong) }\end{array}$ & $\begin{array}{c}\text { 'Consequences for } \\
\text { people like you' } \\
\text { (great) }\end{array}$ \\
\hline know_1: & Right & 27.9 & 41.7 & 29.9 \\
number of member states & Wrong & 19.9 & 37 & 26 \\
know_2: & Right & 21.6 & 36.6 & 26.4 \\
unemployment policy & Wrong & 27.8 & 44.4 & 31.2 \\
know_3: & Right & 22 & 36.9 & 27 \\
health policy & Wrong & 27 & 44.3 & 29.6 \\
\hline
\end{tabular}

Notes: ${ }^{*} \mathrm{~N}$ varies between 18,865 and 16,174 due to missing cases; all connections are significant at the 0.0001 level. 
compared to cultural and civil components of identity), whereas the proportion of those who advocated jus soli and jus sanguinis - being born in Europe and/or coming from European parents - was above average in defining European identity.

When Roger Martin du Gard wrote a sociological novel about a day in the life of the small village of Maupeyrou in 1933, he gave it the title Vieille France [Old France]. The Hungarian translator argued for a change of title to Vén Európa [Old Europe]. The author agreed with the change and declared that it coincided with his intention: to present in a miniature format the general features of the old culture. This story illustrates a feature of the complex relationship of local, national and supranational entities. They not only presuppose each other, and not only do the larger include the smaller ones, but they may condense and replicate each other's characteristics.

Territorial attachments may mutually exclude or reinforce each other. For some people it is important to be attached to their nation or settlement but they only weakly identify with Europe. For others, attachment to the nation does not exclude but rather supports attachment to Europe. However, in research on this topic it seems likely that the technique of inquiry makes identification with mutually exclusive territories appear more strongly. If there is a single question which asks about attitudes to national and European attachment - even if the evaluation is not dichotomous but uses an ordinal scale - the question implies that there are two poles, the national and the European, and they are each other's opposites (Fligstein 2010). There are people, of course, for whom the two concepts mutually preclude one another. Others, however, are easily attached to both nation and Europe. This case applies to most of the elites; and if we do not use a single question for inquires about territorial attachments but several separate questions, then we can find that there is a positive connection between supranational and national, or European and local identities. It is thereby disproved that strong attachment to the nation, region or locality contradicts European identity. The overwhelming majority of national elites identify with Europe, with only one elite member in every seven rejecting it. National and sub-national attachments thus positively correlate with European attachment. General population surveys have shown that an exclusively national attachment is not predominant in Europe. Territorial attachments existing side by side in union are more prevalent among people than the one that suggests exclusiveness (Inglehart 1970; Haller 2007, 2008; Haller et al. 2009b). What proved true in previous research also holds true in the Intune survey: territorial attachments are significantly and positively correlated with each other (see Table 12).

\section{The imperial perspective}

Those who interpret supranational integration as a threat to national values, culture and society often associate the EU with images of a formidable empire ('the Roman army of our age' as one young interviewee who defiantly insisted on his extreme rightwing stance declared). In public thinking - especially within the ideological medium of rightist and leftist populism - the concept of empire is usually associated with negative stereotypes. Furthermore, in an East-Central European perspective, both the Habsburg and the Soviet past elicit recollection of phenomena such as aggression, territorial expansion, exploitation and oppression rather than security, 
TABLE 12

Attachment to Europe, to the Country, to the Region, and to the Settlement: Correlations WITHIN THE GENERAL POPULATION

\begin{tabular}{lcccc}
\hline & Europe & Country & Region & Settlement \\
\hline Europe & & & & \\
Pearson & 1 & 0.300 & 0.205 & 0.142 \\
Sig. & & 0.000 & 0.000 & 0.000 \\
$N$ & 15,760 & 15,745 & 15,670 & 15,733 \\
Country & & & 0.432 & 0.393 \\
Pearson & 1 & 0.000 & 0.000 \\
Sig. & & 15,952 & 16,027 \\
$N$ & & & \\
Region & & & 0.646 \\
Pearson & & & 0.000 \\
Sig. & & & 15,962 \\
$N$ & & & & \\
\hline
\end{tabular}

advancement, catching up or equalisation. Memories of the suppression of the 1848 revolution overshadow the late nineteenth century, just as retaliations following the 1956 revolution overshadowed the emergent 'goulash communism'. This is a remarkable paradox, for chronologically the positive stereotype came after the negative one in both cases. Therefore, those who lived to see both phases either revalued or-more probably-suppressed the image of the negative base. Still, negative associations appear to have stronger effects in posterity. This is presumably because they represent a more effective mobilising force; they offer stronger symbolical clues to the formation of identity than the concepts of progress and security of an amorphous contour. Suffice it to state here that in public thinking the empire is identified with great powers of which not much good can be expected-based on historical stereotypes. The Central European public, on the other hand, is rather disposed to identify with an idealised image of the historical mission of small nations. ${ }^{5}$

Thus the notion of empire is an ideologically laden concept eliciting negative stereotypes in the first place, much more so than the concept of nation. It would be useful, however, to face up to the challenge and deliberate whether applying the term 'empire' to the EU has any scientific merit and whether it has any realistic basis. Such an inquiry is not quite without precedents. There is research that suggests that the concept of empire might be a meaningful coordinate in weighing the alternative future images of the EU (Zielonka 2007; Gravier 2009; Böröcz et al. 2001; Motyl 1997). What are empires? Diverse answers are given by different authors from Eisenstadt to Hobsbawm and Tilly but their common features, as Gravier convincingly demonstrated, are the following: empires are supranational compound entities that represent distinct ideological and cultural patterns differentiable from their parts, are divided into centre and periphery, and tend to expand. Expansion is not necessarily executed by means of aggression. Expansion can also be seen as being motivated by mutually

${ }^{5}$ For example, see Kundera's position in his debate with Havel in 1968 (Kundera 2008; Havel 2008; Chmel 2008). 
expected advantages. In this interpretive frame, the EU appears to satisfy the criteria of being an empire in several regards.

In the research literature, territorially contiguous and divided empires, and somewhat differently, continental and marine empires, are differentiated. Motyl (1997) also speaks about the centre and periphery and points out that mutually reinforcing political, economic and socio-cultural organisations collect about the centre where there is a considerable concentration of decision-making power. The presence or absence of these characteristics separates empires from ethno-territorial federations. More disputable but useful questions are inspired by another of his analytical viewpoints. He claims that the elite and population of the centre are culturally differentiated from the elite and population of the periphery. Within the frames of the empire, the relation of the central elite and the peripheral elite is necessarily dictatorial, whereas the relationship between the elite and the population in general is not. It is a conceptual question whether the dictatorial character of the elite hierarchies is regarded as a distinguishing sign of an empire. ${ }^{6}$ It is, however, a question open to empirical examination to what extent the elites and the public perceive the internal relations of the elites to be asymmetrical.

Another question is how realistic it is to identify centre-periphery inequalities within the EU after the enlargement process. Evidently, Central East European countries were at a massive disadvantage in all respects at the moment of joining the EU, so the question is to what extent these disadvantages became preserved and to what extent there have been deliberate efforts to eliminate them. The phenomenon can be examined from three angles. One may question whether the laws and regulations - the institutions in a broader sense - generate inequalities, intentionally or unintentionally. Secondly, it can be investigated whether in real economic and social processes there are centre-periphery differences that are lastingly maintained. Thirdly, it can also be investigated how people experience and perceive the effects of integration. Symbols and concepts may have obvious impacts on this perception. East European citizens are inclined to understand the concept of 'Core Europe' suggested by Habermas and Derrida as a hidden distinction between first and second class citizenship (Case 2009), even if in a wider and pragmatic Euro-Atlantic political context it may have proven a useful conceptual tool.

There are significant East-West differences both within elites and population samples in terms of the perception of fair acknowledgement of interest, as shown in Table 13. A majority of Eastern, but only the minority of Western elites think that EU decision-makers do not take into account their country's interests properly. Within the general population differences are not so marked because the majority of Western citizens think the same, but Easterners, again, feel so in greater proportions. More than four-fifths (an absolute majority) of elite members agreed with the statement that the interests of some member states carry too much weight at the EU level, but Easterners, again, emphasised this more than their Western counterparts. Within the general population the East Europeans felt (in significantly greater proportions) that, on the one hand, the EU is relatively democratic and that decision makers are competent, but on the other hand they do not care much about what laymen think.

\footnotetext{
${ }^{6}$ I tend to answer in the negative, as it applies only to certain types of empire.
} 
TABLE 13

PERCEPTION OF ACKNOWLEDGEMENT OF INTEREST Within THE EU (\%)

\begin{tabular}{lcccccc}
\hline \multicolumn{5}{c}{ 'Those who make decisions at the EU level do not take enough account of the } \\
interests \\
of my
\end{tabular}

Note: all connections are significant at the 0.0001 level.

\section{A model of attachment to Europe}

Using a logistic regression model I have tried to summarise the impacts of the abovediscussed dimensions. The dependent variable of the model is the European attachment of the population. Macro-level indicators included the country's regional location, religious classification, per capita GDP, indicators of good governance and the political elite's attachment to Europe. Individual level variables on the other hand, besides demography and education, consisted of the following aspects: primordialism, attachment to country, soft Euroscepticism, knowledge, long-term vision and imperial perspective.

What one can learn from the model in Table 14 is that, on a macro level, the EastWest difference has most to do with the respective population's attachment to Europe. There is a smaller, but still significant difference between East European and Mediterranean countries as well. The religious denomination of the country proved to be insignificant in explaining the supranational sentiments of the population. Per capita GDP has a slightly negative impact on European attachment and that of good governance is mixed (regulatory quality has a positive impact, while rule of law and control of corruption a negative impact) if it is controlled for regional differences and individual characteristics of the interviewees. The interesting observation at a macro level is that the impact of the elite's European attachment is significant and positive. That is, if measured using the proportion of members of the political elite who are very attached to Europe and controlled for religious, regional, economic and political country-indicators, the more a country's political elite has supranational sentiments the more the respective population shares them. To the extent that this relationship exists, European identity formation might be indeed called a 'project'.

Among micro-level indicators, gender and age slightly, and higher education strongly influence European attachment. Knowledge about the EU has a double 
TABLE 14

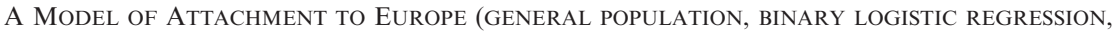
DEPENDENT VARIABLE: ATTACHED)

\begin{tabular}{lccc}
\hline & $B$ & Sig. & Exp $(B)$ \\
\hline WME(1) Western* & 2.134004 & $1.52 \mathrm{E}-09$ & 8.448631 \\
WME(2) Mediterranean* & 1.315906 & $3.4 \mathrm{E}-08$ & 3.728126 \\
Religion(1) Catholic country** & 0.094363 & 0.690329 & 1.098959 \\
Religion(2) Protestant country** & 0.223461 & 0.426296 & 1.250397 \\
Control of corruption & -0.06932 & $2.1 \mathrm{E}-06$ & 0.933024 \\
Rule of law & -0.03403 & 0.020138 & 0.96654 \\
Regulatory quality & 0.13434 & $3.25 \mathrm{E}-12$ & 1.143782 \\
GDP per capita 2006 & $-4.3 \mathrm{E}-05$ & $4.15 \mathrm{E}-05$ & 0.999957 \\
Proportion of political elite strongly & 0.039019 & $4.12 \mathrm{E}-20$ & 1.03979 \\
$\quad$ attached to Europe & & & \\
male & -0.09591 & 0.014626 & 0.908542 \\
Age 50+ & 0.105499 & 0.009814 & 1.111265 \\
Highly educated & 0.397902 & $1.91 \mathrm{E}-17$ & 1.488699 \\
Country has not benefited from membership & -1.05483 & $6.8 \mathrm{E}-133$ & 0.348252 \\
Country's interest is not taken into account & -0.18077 & $7.33 \mathrm{E}-06$ & 0.834627 \\
$\quad$ enough in EU decisions & & & \\
Attachment to the country & 1.689253 & $4 \mathrm{E}-167$ & 5.415435 \\
Primordial view & -0.12024 & 0.007855 & 0.88671 \\
Long term view on EU policy competences & 0.454573 & $5.8 \mathrm{E}-99$ & 1.575501 \\
know1 (number of member states) & 0.379265 & $4.44 \mathrm{E}-16$ & 1.46121 \\
know2 (unemployment policy) & -0.09604 & 0.065438 & 0.908424 \\
know3 (health policy) & -0.17842 & 0.000992 & 0.836591 \\
Constant & -5.32003 & $4.88 \mathrm{E}-08$ & 0.004893 \\
\hline
\end{tabular}

Notes: *ategorical variable, point of comparison: East.

**Categorical variable, point of comparison: Orthodox.

Cox $\&$ Snell $R$ square $=0.21 ;$ Nagelkerke $R$ square $=0.29 ;$ correctly predicted $74.9 \% ; N=17,129$.

impact. Knowledge of quantitative facts has a positive, and qualitative information a weak negative connection, with European attachment. Taking a critical imperial perspective - supposing that EU decision-makers do not take properly into account the interests of one's country - has a slight connection, while pragmatic Euroscepticism has a strong negative connection with European attachment. Primordialism has a weak negative connection, and supporting EU policy competences in the long run has a strong positive connection with European attachment. Attachment to country proves to be not only significant and positive, but the most important single factor at an individual level to positively influence the European attachment of the population.

\section{Concluding remarks}

This essay-based on a comparative survey of 16 countries-investigated the attachment to Europe of national elites and their respective publics. It identified a significant gap between the supranational attachment of elites and the public and raised a set of interconnected questions. Are there similarities among post-socialist countries concerning supranational attachment? Do they differ from their West European and Mediterranean counterparts? What does the connection between national and supranational attachment look like? Do these attachments weaken or 
strengthen each other? What are the macro and micro explanatory factors of citizens' attachment to Europe? Is there a difference between attachment to Europe and attachment to the EU?

The research described in this essay verified that there is a positive connection between national and supranational attachment - even if one controls for individual and regional level differences. Other things being equal, West Europeans, and to a lesser extent Mediterraneans, are more attached to Europe than East European citizens. Research revealed that citizens' supranational attachment is positively influenced when similar - and as a rule more intensive - feelings about attachment are held by political elites.

Another lesson is that, for the sake of conceptual clarity, it is useful to distinguish between attachment to Europe and attachment to the European Union. Although both may positively correlate with support for integration, compounding them may mislead decision-making elites and the wider public as well. Results are contingent upon survey design, but there is evidence which suggests that, when asked in separate surveys or split ballots, attachment to Europe is more widely felt than attachment to the EU. This is intuitively plausible for geographical and cultural reasons, but is worth verifying on a Europe-wide scale.

There are two general remarks to be connected to these findings. First, in relation to European attachment and the nature of remembering, the contradictory character of European attachment derives from the fact that it is popular, but it is only a moderate mobilising force. When no crisis or conflict looms large, many choose attachment as their social point of orientation, but in times of crisis it has little appeal (unless the target of conflict is European attachment itself, in the teeth of some external threat). When, however, there are internal conflicts, they may be easily suppressed by national or ethnic viewpoints. This is revealed by the unsympathetic attitude in Germany towards the Greek financial crisis in spring 2010, or the Hungarian-Slovakian conflict about the question of granting of citizenship to Hungarians living abroad.

Although there are institutions and organisational interests which affect supranational attachment, they seem not to be so effective, convincing or able to mobilise as in the case of national or sub-national attachment. Europe-let alone the European Union-has not often been written about by poets, thundered about by politicians or taught about by teachers, and more importantly, it has not often been a topic of conversation within the family and circle of friends as an object of attachment. That is also part of the common story, serving as an additional explanation for why it is hard to kindle heart-felt sentiments about Europe. Some evidence suggests that political learning is important for elite settlements. One may argue that political learning from others and cultural remembering are also equally important preconditions for integration as far as public sentiments are concerned.

Some tend to remember mainly the glorious past and some are emotionally stirred and united by cherished memories of commonly experienced injustices, suffering and threats. Surveys have found that national attachment and pride differ in that there is a mutual correlation between national pride and a sort of disposition for intolerance. We can only guess what the memory of suppression, injustice and threat predisposes people to. It may predispose them to empathy and tolerance, but it is possible that they can be driven to selfishness, trickery and illiberal notions as well. 
The other remark concerns the role of symbols and concepts in the creation of a European vision. If we focus less on the institutions and more on the processes and perceptions of them, we see that, after the integration of the post-socialist countries, they were shifted into a new institutional space, a peripheral situation in the EU. East Europeans are (slightly more than average) satisfied with the competence of EU decision makers and the way democracy works in the EU. On the other hand they feel also (above the average) that EU decision makers do not take their countries' and their personal interests sufficiently into consideration. This suggests that the modal East European understanding is that the EU is not very fair to them, but it is ruled by competent people in a relatively democratic way. One may add that they feel it is a little better and more competently managed polity than their national polities. The question is not merely about what disadvantages they face and how people perceive them here and now. The more important question is what the tendencies reveal. In any 'imperial age', even the fastest changes are measured in decades and symbols may have generational impacts. This is why the concepts of a 'core Europe' or a 'two-speed Europe' may strengthen negative stereotypes which are interwoven with the vision of the EU as empire, in the long run.

\section{Corvinus University}

\section{References}

Antonsich, M. (2008) 'EUropean attachment and meanings of EUrope. A qualitative study in the EU15', Political Geography, 27, 6, pp. 691-710.

Böröcz, J., Kovács, M., Engel-Di Mauro, S., Sher, A., Dancsi, K. \& Kabachnik, P. (2001) Empire's New Clothes: Unveiling EU-Enlargement, available at: http://aei.pitt.edu/144/, accessed 12 May 2010.

Brubaker, R. \& Cooper, G. (2000) 'Beyond "Identity", Theory and Society, 29, 1, pp. 1-47.

Bruter, M. (2005) Citizens of Europe? The Emergence of a Mass European Identity (New York, Palgrave Macmillan).

Case, H. (2009) 'Being European: East and West', in Checkel, J. T. \& Katzenstein, P. J. (eds) (2009), pp. 111-31.

Checkel, J. T. \& Katzenstein, P. J. (eds) (2009) European Identity (Cambridge, Cambridge University Press).

Chmel, R. (2008) 'Giccs és oligarchák', Kalligram, XVII, July-August, pp. 100-2.

Conti, N., Cotta, M. \& Taveres de Almeida, P. (2010) 'Southern Europe: A Distinctive and More ProEuropean Region in the EU?', South European Society and Politics, 15, 1, pp. 97-118.

Dahrendorf, R. (1980) Life Chances. Approaches to Social and Political Theory (Chicago, IL, Chicago University Press).

Fishkin, J., Lengyel, G., Luskin, R. C. \& Siu, A. (2009) 'The Kaposvár Deliberative Poll: Considered Opinions on Unemployment', in Lengyel, G. (ed.) (2009), pp. 141-47.

Fligstein, N. (2010) Euroclash. The EU, European Identity, and the Future of Europe (Oxford, Oxford University Press).

Gabel, M. (1998) 'Public Support for European Integration: An Empirical Test of Five Theories', Journal of Politics, 60, 2, pp. 333-58.

Geszler, N., Ördög, Z. \& Rigó, E. (2009) Fieldwork course, Logbook, excerpt (Budapest, Corvinus University of Budapest)

Göncz, B. (2009) 'Deliberated Opinions and Attitudes on the EU', in Lengyel, G. (ed.) (2009), pp. 10925.

Gravier, M. (2009) 'The Next European Empire?', European Societies, 11, 5, pp. 627-47.

Haller, M. (2007) 'Economic Elites and Their Role in European Integration and Enlargement', in Lane, D., Lengyel, G. \& Tholen, G. (eds) (2007) Restructuring of the Economic Elites after State Socialism. Recruitment, Institutions and Attitudes (Stuttgart, Ibidem Verlag), pp. 317-46.

Haller, M. (2008) European Integration as an Elite Process. The Failure of a Dream? (New York, Routledge). 
Haller, M., Jowell, R. \& Smith, T. W. (eds) (2009a) The International Social Survey Programme, 1984 2009. Charting the Globe (New York, Routledge).

Haller, M., Kaup, G. \& Ressler, R. (2009b) 'National Identity in Comparative Perspective', in Haller, M. et al. (eds) (2009a), pp. 222-41.

Havel, V. (2008) 'Cseh sors?', Kalligram, XVII, July-August, pp. 88-91.

Hooghe, L. \& Marks, G. (2005) 'Calculation, Community and Cues. Public Opinion on European Integration', European Union Politics, 6, 4, pp. 419-43.

Immerfahl, S., Boehnke, K. \& Baier, D. (2010) 'Identity', in Immerfahl, S. \& Therborn, G. (eds) (2010) Handbook of European Societies. Social Transformations in the 21st Century (New York, Springer), pp. $325-53$.

Inglehart, R. (1970) 'Cognitive Mobilization and European Identity', Comparative Politics, 3, 1, pp. 45-70.

Kundera, M. (2008) 'Cseh sors', Kalligram, XVII, July-August, pp. 83-87.

Lengyel, G. (ed.) (2009) Deliberative Methods in Local Society Research. The Kaposvár Experiences (Budapest, CUB-CESR, Uj Mandátum).

Lengyel, G. \& Borbála, G. (2010) ‘A magyar EU-tagság a közvéleményben’, in Kolosi, T. \& Tóth, I. G. (eds) Társadalmi riport 2010 (Budapest, Tárki), pp. 527-48.

Lengyel, G. \& Göncz, B. (2009) 'Elites’ Pragmatic and Symbolic Views about European Integration', Europe-Asia Studies, 61, 6, pp. 1059-77.

Lengyel, G. \& Ilonszki, G. (2010) 'Hungary between Consolidated and Simulated Democracy', in Best, H. \& Higley, J. (eds) (2010) Democratic Elitism: New Theoretical and Comparative Perspectives (Leiden, Brill), pp. 153-71.

Motyl, A. J. (1997) 'Thinking about Empire', in Barkey, K. \& von Hagen, M. (eds) After Empire. Multiethnic Societies and Nation-building (Oxford, Westview Press), pp. 19-29.

Müller, B. \& Haller, M. (2009) 'Social Identities in Comparative Perspective', in Haller, M. et al. (eds) (2009a), pp. 175-96.

Szczerbiak, A. \& Taggart, P. (eds) (2008) Opposing Europe? The Comparative Party Politics of Euroscepticism. Vol. 2. Comparative and Theoretical Perspectives (Oxford, Oxford University Press).

Tajfel, H. (ed.) (1982) Social Identity and Intergroup Relations (Cambridge, Cambridge University Press).

Vetik, R. (2003) 'Elite vs. People? Eurosceptic Public Opinion in Estonia', Cambridge Review of International Affairs, 16, 2, pp. 257-71.

Zielonka, J. (2007) Europe as Empire. The Nature of the Enlarged European Union (Oxford, Oxford University Press). 